https://doi.org/10.37208/tgn27216

\section{Some significant botanical records from Loch Awe, Argyllshire, Scotland in 2019}

\author{
J. Waddell
}

RSPB Centre for Conservation Science, 2 Lochside View, Edinburgh Park, Edinburgh EH12 9DH

E-mail: jeffwaddell11@yahoo.co.uk

2019 was the final year of fieldwork for the Botanical Society of the British Isles (BSBI) Atlas 2020 project, which aims to map the distribution of vascular plant species across Great Britain and Ireland. As part of an RSPB sabbatical funded by RSPB Scotland and the Blodwen Lloyd Binns Bequest Fund, I spent eleven days recording in Argyllshire, Scotland during the year to contribute to the Atlas 2020 project. A total of 1,771 botanical records was collected and this Short Note describes some of the most interesting plant species encountered in the Loch Awe area, particularly those that are significant in the Argyllshire or U.K. context.

On 31st May, whilst recording on the south side of Loch Awe off the B840 near the western edge of Eredine Forest at NM91630518, Sarah Sanders and I found a population of Mackay's horsetail Equisetum $\times$ trachydon. This taxon is the hybrid between rough horsetail Equisetum hyemale and variegated horsetail $E$. variegatum. It was growing on the loch edge in a typically lowland situation at $40 \mathrm{~m}$ above sea level. This taxon has fewer than ten mapped occurrences this century in Scotland (BSBI, 2020) and is described as nationally rare, i.e. found in not more than 15 different hectads $(10 \mathrm{~km} \times 10 \mathrm{~km}$ squares $)$ in the U.K. since 1987 (Stace, 2019). This occurrence is the first record in the BSBI database for Argyllshire (BSBI, 2020).

Published descriptions of its ecology elsewhere in the U.K. describe highly calcicolous habitats such as dune slacks, river banks and flushes in open damp vegetation with low competition from other plant species (Page, 1982). The habitat at Loch Awe is similar in the open and damp conditions, but did not appear particularly calcareous. Calcicolous herbs such as globeflower Trollius europaeus and northern bedstraw Galium boreale were growing nearby on dry rocks on the bank, but the wet shingle where Mackay's horsetail grew occurred in the drawdown zone of Loch Awe itself. Measurements recorded in Scottish Natural Heritage's Standing Waters Database record a $\mathrm{pH}$ of 5.83 in the north and 7.13 in the south of the loch, indicating that the loch varied from slightly acid to slightly alkaline (Lassiere et al., 1993). The shingle substrate could have been calcareous, given the base rich rocks nearby on dry land, but no other plant species were growing in association with the horsetail to confirm this.

None of the hybrid parents were seen nearby, but this is typical for this taxon, which is capable of dispersing long distances as viable stem fragments (Page, 1982). There are records of variegated horsetail from nearby at the south western end of Loch Awe, on the loch shore by B.H. Thompson from 1988 and 1992 (BSBI, 2020). It would be worth checking these localities again, as Mackay's horsetail would appear more likely in this habitat than variegated horsetail, and the two can be easily confused. The nearest records of rough horsetail are about $50 \mathrm{~km}$ away. Mackay's horsetail appears to be a relict here, persisting vegetatively around the loch edge in the absence of at least one and probably both parents. Its vegetative fragments are likely to be distributed around the loch by wave action and draw down, which also create the open, low competition environment it needs to persist.

The most notable aquatic plant I recorded during field work in Argyllshire in 2019 was the introduced neophyte Nuttall's waterweed Elodea nuttallii, which I collected with a grapnel from the bank of Loch Awe by Kilchurn Castle (NN133276) on 3rd June. It was sampled along with Canadian waterweed E. canadensis, shoreweed Litorella uniflora and a quillwort, possibly spring quillwort Isoetes echinospora, but inconclusive as ripe spores were not available. This is one of only several records of Nuttall's waterweed from Argyllshire and the first record from Loch Awe. This North American species was first recorded from the wild in the U.K. in 1966 (Stace, 2019) and has since spread rapidly throughout lowland England north to the Scottish Central Belt. Elsewhere in Scotland it has a rather patchy distribution, stretching northwards to the Moray coast on the east. On the west side of the mainland, its current range extends to just north of Fort William, Highland (BSBI, 2020).

On 2nd June whilst descending the forest track by Kilmaha (NM942084) I noticed a mature bush of Californian honeysuckle Lonicera involucrata growing with native, self-sown scrub of the same age. It was a few hundred metres distant from the house and was not growing in a place where it is likely to have been planted. It was on the edge of the forest track and will likely be removed to keep the track open once it reaches a certain size. This is the first time this introduced species has been recorded from the wild in Argyllshire. It has a very scattered U.K. distribution, with the current nearest record being from Dunbartonshire, about $40 \mathrm{~km}$ to the south east. There are currently about 25 recorded hectad occurrences in Scotland (BSBI, 2020).

I would like to thank RSPB Scotland for supporting my sabbatical in 2019, including work in Argyllshire. I would also like to thank the Blodwen Lloyd Binns Bequest Fund and Glasgow Natural History Society for assisting with expenses for field work in Argyllshire and 
Dunbartonshire. I would like to thank Sarah Sanders for accompanying me on some of the above field work and Dr Fred Rumsey at the Natural History Museum, London for determining Mackay's horsetail from collected material.

\section{REFERENCES}

BSBI (2020). https://database.bsbi.org/ Accessed $8^{\text {th }}$ April 2020

Lassiere, O., Harding, T. \& Jackson, J. (1993). Standing Waters Database. Scottish Natural Heritage, Inverness.

Page, C.N. (1982). The Ferns of Britain \& Ireland. Cambridge University Press, Cambridge.

Stace, C.A. (2019). New Flora of the British Isles. (4th edition). C\&M Floristics, Suffolk. 